microdensitometer; navigational wireless system; photosensitive cells; polarograph; potato harvester; resonant electronic circuits; selective weed killers, triiodothyronine; universal joints; variable speed induction motors; and visual flying aids.

Between them these major inventions earned $£ 209,662$, of which $£ 104,701$ came from two only, both concerned with drugs and mostly from the United States. Exploitation receipts by way of royalties, option payments and the like increased to $£ 279,435$, compared with $£ 259,902$ in 1960-61. The Corporation now holds the rights in 1,064 United Kingdom patents and patent applications and in 2,491 oversoas ones, while the Corporation's Development Companies hold a further 705 United Kingdom and overseas patents and patent applications. A further 42 licence agreements with United Kingdom firms brought the total in foreo to 516, whilo 6 further licence agreements with overseas firms raised the lattor total to 53. At the end of the year the Corporation was providing financial and other assistance for 35 development projects, of which 5 were new, and exponditure on development was $£ 1,099,030$, compared with $£ 811,730$ in $1960-61$, and forward commitments amounted to $£ 850,000$. Most of this expenditure was concerned with the hovercraft, olectronic computer
(Atlas and Emidec) and Dracone projects. Some $£ 140,000$ was written off when work was stopped on a number of projects.

Of 911 inventions communicated to the Corporation during the year (compared with 973 in 1960-61), 161 were from universities in the United Kingdom (115 in 1960-61), but only 257 were from Government Departments and Research Councils, compared with 312. For nationalized industries the figure was 19 (2), industrial research association 11 (8), and for private firms and individuals in the United Kingdom 406 (466). At the end of the year 23 potential development projects in a wide range of technological fields were under consideration, more than half of these deriving from private firms and individuals. Of 243 patent rights assigned during the year, 167 were from Government Departments and Research Councils and 69 from universities. The new projects reported for the first time include equipment for the rapid and automatic analysis of raw milk and other emulsions; development of a refrigerator for temperatures in the region $4^{\circ}-20^{\circ} \mathrm{K}$ using expansion turbines with holium as tho working substance and running on helium bearings; JASTAC fastening techniques; multiple fixed speed motors; and water control in arid zonos.

\title{
THE INSTITUTE FOR NORTHERN STUDIES, UNIVERSITY OF SASKATCHEWAN
}

\begin{abstract}
$\mathrm{T}$ THE Institute for Northern Studies, University of Saskatchewan, was authorized and the director appointed in January 1960 to aid original research and academic work on northern problems and to assist the training of humanists, scientists, engineers and others interested in northern problems and in the inhabitants of this part of Canada. The Institute possesses no research staff of its own, and research will be carried out under the supervision of the various University departments.

The first annual report of the Institute* summarizes the work carried out during the summer of 1960 on seven projects: a plant ecology study, with special reference to the forest vegetation; a systematic collection of small mammals and another of biting insects; a study of the history and economics of water transport on the Athabasca-MacKenzie River system and another of some

* Institute for Northern Studies, University of Saskatchewan. First Annual Report, 1960-1961. Pp. 11. (Saskatoon, Canada: Institute for Northern Studies, The University, 1961.)
\end{abstract}

factors in the economics of the Lake Athabasca mining area; a study of the trace elements in the Coronation mine, Flin Flon, and one of a radio-communication system in the very-high-frequency field which, it is believed, will operate even under conditions where electric storms are prevalent.

Further accounts of these projects are included in the second annual report, $1961-62 \dagger$, as well as ornithological studies in the Lake Athabasca district; the commercial fishing industry of Northern Saskatchewan; Saskatchewan's role in a changing fur industry; an investigation of the sand dunes in the vicinity of the William and McFarlane Rivers on the south shore of Lake Athabasca; and of the deep seismic sounding of the Earth's crust in the vicinity of Flin Flon. A list of publications resulting from work assisted by the Institute is included.

$\uparrow$ Institute for Northern Studies, University of Saskatchewan. Second Annual Report, 1961-1962. Pp. 12. (Saskatoon, Canada: Institute for Northern Studies, The University, 1962.)

\section{MAGNETO-TELLURIC EFFECTS OBSERVED IN DALLAS, TEXAS, FROM THE JULY 9, 1962, HIGH-ALTITUDE NUCLEAR EVENT}

\section{By JACK J. BURCH and ARTHUR W. GREEN, jun.}

Texas instruments Incorporated, Dallas, Texas

$\mathrm{T}$ HE U.S. Atomic Energy Commission detonated a megaton-range nuclear device over Johnston Island at an altitude of 250 miles on July 9, 1962, at about $09 \mathrm{~h}$ 00 min 09 sec, U.T.

It was expected that magnetohydrodynamic waves generated by the expanding blast plasma would propagate in various modes across and down the lines of force of the Earth's field, as well as through the exospheric ducts postulated by Bomke et al. ${ }^{x}$. Expected velocities of propagation range from several hundred to several thousand kilometres per second ${ }^{2}$. At the base of the ionosphere, where magnetohydrodynamic wave propagation is no longer possible, some of the wave energy would be converted to ordinary electromagnotic waves which would then propagate around the world at the speed of light. Thus, the electromagnetic waves resulting from the various magnetohydrodynamic modes would be seen by magnetometers and Earth current (telluric) sensors sevoral seconds after the detonation. In addition to thoso delayed signals, Troitskaya (U.S.S.R.), during the 1958 Argus test series, observed direct, speed of light, signals which marked the instants of the events ${ }^{3}$. Because these instantaneous signals suffored great attenuation in travelling as electromagnotic waves through the highly conductive ionosphere, they were seen only on very sensitive Earth current systems. 